Dino Abazović, Sarajevo

\title{
O RELIGIJI I RADU AKADEMIKA IVANA CVITKOVIĆA
}

Dijagnosticirajući akutne probleme sociološke teorije današnjeg vremena, gotovo naivno pitajući šta je pošlo krivo, Nicos Mouzelis podsjeća nas, između ostalog, da ukoliko posmatramo ekonomske, političke, religijske ili obrazovne sfere, uvijek je moguće prepoznati društvene aranžmane ili pravila koja su pretežno tehnologijske prirode, prisvajajuća, ili ideologijska.

(Mouzelis 2000) ${ }^{1}$

Ne gubeći iz fokusa njihov ideologijski karakter, prekomponirat ću Mouzelisovu postavku na sljedeći način - prve dvije sfere (ekonomska i politička) ključne su za današnje razmatranje, uz ostale, i obrazovne sfere u Bosni i Hercegovini. Mjesto i uloga religije u obrazovnoj sferi, odnosno uticaj religije na prisvajajući, ideologijski karakter društvenih aranžmana i pravila u obrazovnoj sferi, također je posve evidentan.

Za razliku od prijeratnog perioda, kada je dostignuto ulaganje u nauku u Bosni i Hercegovini bilo od 1,5 odsto bruto društvenog proizvoda (BDP), sve ozbiljnije analize (po)kazuju da sistem finansiranja nauke danas gotovo da nije ni uspostavljen. Prema nekim proračunima, a na osnovu zbira budžetskih stavki svih ministarstava za nauku (entitetskih i kantonalnih), državna ulaganja u nauku su 0,05 odsto BDP-a, s tim da je taj BDP dostigao tek 50 odsto onoga iz 1990. godine (Matić 2004).

Ova zemlja se nalazi u naučnoj izolaciji i, u poređenju sa zemljama u regionu, $\mathrm{BiH}$ je po tom pitanju na najnižem podioku mjerne ljestvice. Također, kada je u pitanju opći rang nauke, $\mathrm{BiH}$ je kumulativno na najnižem stupnju od svih zemalja regiona. Sve navedeno dakako reflektira aktualnu poziciju, mjesto i domete znanstvenog rada domaćih akademskih radnika, nastavnog i istraživačkog osoblja.

\footnotetext{
${ }^{1}$ Iako u fusnoti, treba pripomenuti da se Mouzelis pri daljnjoj razradi navedenog referira na T. Parsonsa i njegovo djelo Social Systems and the Evolution of Action Theory (Parsons 1977).
} 
Dodatno, u Bosni i Hercegovini je već jedan relativno duži vremenski period prisutan trend "sakraliziranja" znanja (i nauke), napose humanističkih i društvenih znanosti. U tom kontekstu, naročito je sociologiji, koja jeste nauka o društvu par exellance, a zahvaljući vladajućim (etno-nacionalnim) ideologijama koje hoće pošto po to opravdati o(p)stanak na vlasti, namijenjena uloga eventualno tek ancilla religionis - posebno u pitanju neupitnosti "svetih istina".

Dakako, "problemi sa profesijom" evidentno nisu podložni ili uzrokovani samo ekonomskim i/ili zakonskim determinantama, niti samo političkim intervencijama, već i specifičnostima "esnafskog" habitusa.

Prije skoro četrdeset godina o tome je najilustrativnije pisao Rudi Supek razmatrajući zanat sociologa: "Samo jedan oblik nerazvijene znanstvene svijesti, koja se još nalazi u fetišističkoj fazi naučnog mišljenja, sklon je vjerovanju da postoji jedan jedini teorijski okvir, i jedna jedina njemu adekvatna metoda kojom se sigurno može doći do istine. U znanstveno nerazvijenim sredinama učenjaci se često ponašaju kao magi koji vrše prvotnu inicijaciju još nedoučenih glava u tajne znanosti i prikazuju im znanstvenu metodu kao neko Sveto otajstvo, što će nakon pričesti prožeti duh mladog čovjeka i odvesti ga nepogrešivim putem znanstvene istine. Naravno, ti će se magi kasnije podrugivati takvim mladim i 'metodološki ograničenim glavama' koje su im trebale da bi pokorno i sa strahopoštovanjem obavile za njih, reći će važan posao, da su njihovi učenici ostali samo na razini 'laboranata' i da ništa nisu shvatili od pravog kreativnog znanstvenog posla. Na žalost, takvom ponašanju valja dodati i onu fanatičku samouvjerenost kojom ponekad zrače pojedinci, koji nedostatak teorijskog obrazovanja žele kompenzirati metodičkom pedantnošću i apsolutizmom.” (Supek 1983: 76-77)

Imam tu privilegiju da sam od početka akademske karijere, sarađujući sa profesorom Ivanom Cvitkovićem, svjedočio kako je unatoč svemu i ma koliko dali za pravo Supeku, ipak moguće drugačije. Cvitković je inicirao, a potom pratio moj akademski razvoj, prvo članstvom u komisiji za odabir asistenta kada sam počeo raditi na Fakultetu, potom mentorstvima magistarskog i doktorskog istraživanja, sve do članstva u komisijama za izbore u zvanja docenta, vanrednog profesora te konačno redovnog profesora na Univerzitetu. I niti jednom, ali baš niti jednom nije demonstrirao autoritarnost, napose ne $u$ onim ne tako čestim situacijama kada nismo dijelili zajedničke poglede, odnosno kada smo imali drugačija mišljenja o nekim znanstvenim fenomenima. Držao je do integriteta suradnika i činio sve u njegovoj moći da se potencijal, koliko god da ga je bilo, ostvari i potvrdi znanstvenim radom.

Stoga je i insistirao na tome da je neophodno, pored revitalizacije empirijskih, reklo bi se klasičnih istraživanja, disciplinu poput sociologije religije 
razumijevati u kontekstu onog zahtjeva Gustava Guizzardia (o čemu sam i sâm često pisao), koji je istaknuo tezu o potrebi nadilaženja sociologije religije koncipirane i prakticirane kao "sociologije religije pojedinca i vrijednosti" u smjeru razrade političke sociologije religije. I to one političke sociologije religije usredotočene ponajprije na problem konsenzusa, i to konsenzusa ne kao unaprijed danog, nego kao konstruiranog, te isto tako ne kao svojevrsnog ugovora između jednakih, nego kao dijalektičkog, koji se stalno stvara i rastvara između strana sa nejednakim političkim, kulturnim, simboličkim i inim kapitalima (v. više u Vrcan 1995: 231-254).

A to nije (bio) jednostavan zadatak. Iako je poznato je da je u prethodnih pedesetak godina u Bosni i Hercegovini sproveden relativno mali broj empirijskih istraživanja koja su razmatrala religiju i konfesiju, Cvitković je proveo jedno od prvih poslijeratnih istraživanja, i to školske 2000/2001. godine među 259 studenata prve godine Univerziteta u Sarajevu, Univerziteta u Banja Luci i Sveučilišta u Mostaru. Dobiveni rezultati će biti dodatna ilustracija uvidima koji su objavljeni u tada već trećem i četvrtom dopunjenom izdanju Sociologije religije štampanim 2004. i 2005. godine. ${ }^{2}$ Generacije studenata na Fakultetu političkih nauka i kasnije Filozofskom fakultetu Univerziteta u Sarajevu sticali su znanja iz tog, po mom skromnom sudu, najboljeg udžbenika iz te discipline na našim jezičkim prostorima. A te 2004. iz štampe će izaći i Konfesija u ratu u kojoj su ne samo predstavljeni još neki od rezultata dobivenih u pomenutom istraživanju već taj rad ostaje do danas usamljeno štivo domaćih autora koji tretiraju ulogu religije i konfesije u ratnom periodu (1991-1995).

Kraj prošlog i početak aktualnog milenija, između ostalog, karakterizira i to da gotovo nema dana a da se neki čin nasilja, fizičkog ili verbalnog, u nekom dijelu svijeta, ne dovede u vezu sa religijom i prenese preko medija, bilo "tradicionalnih" ili "novih". Već izvjesno vrijeme također značajan broj stručnjaka ukazuje na situaciju u kojoj se religija, za razliku od ranije, sa zadnjih stranica u štampi tematizira na naslovnim i prvim stranama, umjesto u prilozima o povijesti i kulturi dominira u udarnim terminima i političkim temama elektronskih medija, na internetu milioni korisnika ispisuju žučne i neostrašćene komentare...

Dakako, uzevši u obzir da svako "zna” šta je religija, time si uzima za pravo komentirati, tumačiti, kritizirati, podržavati, osporavati... A religija kao religija, rekao bi William James, već samom činjenicom da ih ima toliko mnogo i da su međusobno toliko različite, dovoljna je kao dokaz da riječ "religija" ne

\footnotetext{
${ }^{2}$ U ovom tekstu nećemo navoditi kompletnu bibliografiju akademika Ivana Cvitkovića, već odabranu selekciju djela u funkciji teksta i konteksta.
} 
može da se odnosi ni na jedno pojedinačno načelo ili suštinu, već da je prije njihov zajednički naziv.

Svojevremeno je nedavno preminuli američki publicista i dobitnik Pulitzerove nagrade Charles Krauthammer u magazinu Time pisao o problemu religioznosti u suvremenom svijetu i otvorio pitanje religijskih preferencija te žurnalistički poentirao - “...tamo gdje je religija trivijalizirana, najvjerovatnije neće doći do progona. Kada se vjeruje da besmrtnost vaše duše ovisi o religiji, inkvizicija nastupa veoma lako; kada se vjeruje da je religija radosna korisnička preferencija, religijska tolerancija cvijeta veoma lako. Na kraju krajeva, ne progonimo ljude po osnovu njihovog ukusa prema automobilima. Zbog čega onda zbog njihovog ukusa prema Bogu?” Po njemu, zato što je u našoj sekulariziranoj kulturi forma religijske netolerancije koja preživljava zasnovana i prisutna kod onih za koje religija nije slobodna preferencija i stvar ličnog izbora, već stvar ubjeđenja. U našim okolnostima i stvar rođenja, a ne stvar prakse i izbora.

Tako i politika u Bosni i Hercegovini, ali i u regiji, svoje veze sa religijom predstavlja prije svega, opšte je to mjesto, na osnovi povijesne simbioze između etniciteta i konfesija na ovim prostorima. "Svoj odgovor njima" Cvitković je ponudio u nekoliko knjiga, možda najdetaljnije u sad već "ediciji" Socioloških pogleda na religiju i naciju $(2005,2012)$.

Tvrda činjenica je da kada se "religijske" granice preklapaju sa etničkim, rasnim, jezičkim ili državnim granicama, mogućnost da će religija biti "uvučena" u konflikt raste eksponencijalno. Umjesto pitanja ko je kriv, Cvitković na stranicama svojih knjiga najčešće pita zašto?

U vrijeme kada se u znanstvenoj perspektivi (iznova) raspravlja o ulozi religije u javnom prostoru, jedan broj autora prvenstveno se fokusira na potrebu za novim razumijevanjem "političkog", što ukazuje i na problem svojstven oživljavanju "političkih teologija".

Kontekstualno, to ne iznenađuje jer, iako je u XX stoljeću došlo do radikalne promjene u vezama između države i vjerskih zajednica, to u svakom slučaju ne znači da je došlo do radikalnih promjena u odnosu religija - vjerska zajednica - politika. I mislim da je to bio jedan od motiva da Cvitković napiše te ukoriči tekstove u knjizi pod naslovom "Religija u raljama politike" (2019).

Nekako u pravi čas, jer ni dan danas najveći dio stanovništva Bosne i Hercegovine ne pravi ključnu razliku između etničkog / nacionalnog i konfesionalnog identiteta, što političkim donosiocima odluka omogućava da se ponašaju po matrici stare feudalno-imperijalističke koncepcije, koja je politička par exellance - po kojoj svaka zajednica i svaka teritorija imaju svoju religiju 
i svaki pojedinac i pojedinka prvo pripadaju svojoj zajednici, pa tek onda političkom prostoru.

Inače, kod nas dodatnu konfuziju stvara i određenje političkog prostora u kontekstu politike i religije. Nominalno-pravno, bosanskohercegovačka država danas je sekularna, ali razumijevanje koji su to temeljni principi takvog uređenja nerijetko je potpuno pogrešno protumačeno i, shodno tome, u javnom prostoru artikulirano. Za razliku od prethodnog socijalističkog perioda društveno-političkog uređenja odnosa države i religijskih zajednica, za koji možemo govoriti da je u prvom periodu na razini društva bio obilježen ideološki isforsiranom i prisilom nametanom ateizacijom, a kasnije dominantno politički i državno protežiranim rigidnim sekularizmom, aktualni period obiluje mnoštvom primjera klerikalizma i povlaštenim položajem organizirane religije dominantnih religijskih zajednica u javnom prostoru.

Sociološki je razvidno već duže vrijeme da obično dominantna, vladajuća grupa unutar društvenog sistema određuje kontrolnu ideologiju, koja je ojačana u obrazovnom, komunikacijskom i sistemu religijskih vjerovanja. Religija i religijske zajednice, koje imaju snažnu ulogu u oblikovanju ideje i percepcije socijalne pravde, a time i u legitimaciji društvenih sistema, mogu biti označene kao snažan saveznik bilo dominantnim, vladajućim skupinama, ili potlačenim skupinama koje traže oslobođenje od nepravednih sistema. Dominantne i potlačene skupine, čak i one koji dijele jednu religijsku tradiciju, mogu koristiti različite teologije, vjerske interpretacije ili pripovijesti te podržati ili dovesti u pitanje legitimitet ideologije.

Sve relevantne studije u posljednje vrijeme pokazale su da nije jedini problem u vezi s religijom samo detaljno neznanje o religiji, problem je zapravo praktična, odnosno življena religioznost. A takvo šta nema gotovo nikakve veze s religijom kao takvom, već s ličnim setom vrijednosti koje pojedinci unose u religiju i apliciraju u religiju. Još je William Shakespeare ustvrdio - "i đavo može citirati iz Biblije za sopstvene svrhe". Doista, sveti spisi su među najviše zloupotrijebljenim dijelovima religijskih sistema, gotovo u istoj mjeri kao i religijski simboli. Kako drugačije objasniti da su se recimo dijelovi Biblije koristili da bi se opravdalo ropstvo, ali jednako tako i da bi se ukinulo ropstvo. Ili da neki ljudi citiraju Kur'an kako bi počinili akt nasilja u kojem stradaju nevine osobe, a drugi ljudi citiraju isti sveti spis kako bi odbacili nasilje navodeći da onaj koji ubije jednu nevinu osobu kao da je ubio cijelo čovječanstvo! Ne radi se o svetim spisima, dakle, već o pojedincima i njihovim vrijednostima, a još prije o namjerama da djeluju pozitivno ili devijantno, i onda traže za takvo šta argumente i opravdanje. A Cvitković o svemu tome piše još 1997. godine u "Društvenoj misli u svetim spisima". 
Dodatno, religijski obredi i njima imanentne ceremonijalne aktivnosti su dugi vremenski period predmetom znanstvene pažnje i istraživanja, ali su jednako tako sva ta istraživanja bila, i ponekad još uvijek jesu, uvjetovana kako kulturnim perspektivama, disciplinarnim pretpostavkama, tako i raznorodnim historijskim, pa i ideološkim agendama. Zašto je to tako?

U sociološkoj perspektivi to Cvitković minuciozno obrađuje u Sociologiji obreda (2014), jer je obred, ili kako je to još uobičajeno u literaturi pod terminom ritual, uz vjerovanje, središnji pojam za razumijevanje religije. Vjerovanje i obredi su zapravo ta ključna poveznica svih onih ključnih elemenata oko kojih se većina sociologa slaže da su potrebni za definiranje religije - nadnaravno, sveto, simboli, običaji i obredi, religijska zajednica i vođstvo te etičke ili ćudoredne definicije. Još od Emilla Durkheima i glasovitih Elementarnih formi religijskog života, gdje je religija ništa drugo do "...unificirani sistem vjerovanja i praksi koje se odnose na sveto...", pa do suvremenih sociologa religije, poput Henta De Vriesa, koji polazi od postavke da je "religija kvintesencijalno razlika, u isto vrijeme spaja ali i razdvaja”.

Ako bismo vjerovanje u određenom smislu mogli razumijevati kao najčešće unutarnji, individualni aspekt religije i religioznosti, ne zanemarujući pritom činjenicu da se sistem religijskih vjerovanja ne iscrpljuje u individualnom aspektu, obred bi tako onda bio najčešće spoljni, kolektivni aspekt religije i religioznosti, koji se dakako ne iscrpljuju samo u tom aspektu. "Preko obrednih aktivnosti grupa kolektivno pamti svoja zajednička značenja i revitalizira svjesnost o sebi samoj. To ima značajne posljedice i za grupu i za sve pojedinačne članove. Grupa obnavlja svoj zanos i smisao ujedinjenosti, a pojedinci se identificiraju sa grupom i njenim ciljevima" piše sociologinja religije Meredith McGuire sintetizirajući teoriju spomenutog Durkheima, ali i antropologa Cliforda Geertza. Nije nas stoga iznenadila činjenica da je Cvitkovićeva Sociologija obreda, koja koindicira s periodom najzrelije faze njegova znanstvenog djelovanja kao sociologa religije, ima za temu upravo obrede.

Spomenuo sam najzreliju fazu i želim samo ukratko pojasniti šta pod tim podrazumijevam - napisati knjige koje Cvitković potpisuje u posljednjih desetak i "kusur" godina (uz spominjane tu su i Socijalna naučavanja u religijama - 2007, Rječnik religijskih pojmova - 2009, Moj susjed musliman - 2011, ili Religija u zrcalu teorija - 2016) s takvom strukturom, i uz tako impozantan broj informacija i ilustracija, kako iz svetih spisa, tako iz bibliografskih jedinica $^{3}$, ali i iz iskustva istraživača, a da su u direktnoj vezi s centralnim

\footnotetext{
${ }^{3}$ Inače, u gotovo svim Cvitkovićevim knjigama se nalazi veoma važan dio, nekima se može učiniti tek kao tehnička formalnost (što je po meni pogrešno razumijevanje) - kazalo imena
} 
tematom, može biti samo pothvat koji nastaje $u$, i kao rezultat, najzrelije faze znanstvenog rada.

Sve u svemu, u prvom poglavlju zbornika The Handbook of Sociology of Religion, u izdanju The Cambridge University Pressa iz 2003. godine, urednica i autorica Michele Dillon podsjeća nas čemu još istraživanje religije $u$ sociološkoj perspektivi:

1. religija i razumijevanje društvenog - odnosno religija još uvijek ima pivotalnu ulogu u procesu kojim značajna većina stanovnika tumači svoje živote i društveni, kao i fizički svijet oko njih;

2. religija kao objašnjenje društvenog - odnosno religija ne samo da ljudima pomaže da razumiju društvena iskustva i institucionalne prakse, ona im također služi kao moćan izvor objašnjenja širokog spektra društvenih stavova i ponašanja;

i konačno

3. religija kao emancipatorno sredstvo - odnosno različite na religiji zasnovane grupe (faith-based groups) postavljaju izazove nejednakostima kako unutar religijskih institucija tako i u drugim institucionalnim i društvenim oblicima organiziranja.

Do koje mjere i na koji način su ovako skicirane teze od važnosti za sociološka istraživanja religije prisutne u ovdašnjim radovima $i$ istraživanjima posebno je pitanje, a bio sam počastvovan da sam zajedno s akademikom Cvitkovićem ukazao na probleme sa sociologijom religije u $\mathrm{BiH}$ u tekstu objavljenom u zborniku radova YUNIR-a iz 2008. godine i kasnije u zborniku radova o stanju i perspektivama sociologije (u Cvitkovićevom uredništvu) za ANUBiH.

Ipak, za bosanskohercegovački konktekst vjerovatno važnije jeste ukazati na to šta bi trebalo uzeti u obzir pri budućim istraživanjima. Bez obzira na to što su sociolozi raspravljali, i još uvijek raspravljaju, o granicama između religijskog i nereligijskog i, shodno tome, raspravljaju o tom šta bi trebalo uzimati u obzir, a šta ne, stara polazna premisa i dalje je nepromijenjena. Tako da, ukoliko je neko u svom polaznom stajalištu orijentiran na tzv. supstancijalni pristup razumijevanju i definiranju religije ( $\mathrm{tj}$. šta religija jeste, odnosno šta nije), volens nolens teorijski je primoran biti restriktivan (odnosno mnogo toga izostaje). Ukoliko je pak orijentiranost ka funkcijama koje religija ima u društvu (tj. šta religija čini, koje su joj funkcije), teorijski je primoran biti ekspanzivan (odnosno uključuje suviše toga).

kao i kazalo pojmova - što je na žalost sve rjeđe prisutno u našoj recentnijoj publicističkoj praksi. 
Bilo kako bilo, "problem nije u nejasnoj ili varijabilnoj prirodi 'religije kao takve', šta god to moglo da znači, već u društvenom kontekstu koji tu nejasnoću čini razumljivom” (Bayer 2003). U tom svjetlu pitanje koje moramo postaviti o suvremenoj religiji više nije "šta je religija" ili "šta religija čini" (supstantivne nasuprot funkcionalističkim definicijama), već pitanje "koja religija" i "kako se religija nadaje (ili u šta se religija pretvara)".

A upravo je to vertikala koja povezuje Cvitkovićev rad na proučavanju religije svih ovih godina i svako ko bude želio da razumije ulogu religije u našem društvu, morat će ga čitati iznova i iznova.

\section{Literatura}

Beyer, Peter (2003), Social Forms of Religion and Religions in Contemporary Global Society.

U: M. Dillon (ur.) The Handbook of Sociology of Religion, Cambridge University Press, Cambridge.

Dillon, Michele (2003), The Sociology of Religion in Late Modernity. U: M. Dillon (ur.) The Handbook of Sociology of Religion, Cambridge University Press, Cambridge.

Matić, Božidar (2004), Potrebno je usvojiti politiku nauke u BiH. U: Bosna i Hercegovina na putu ka modernoj državi? - Perspektive i prepreke, Fondacija Heinrich Boll / Asocijacija $\mathrm{BiH}$, Sarajevo.

Mouzelis, Nicos (2000), Sociologijska teorija - što je pošlo krivo? Dijagnoza i pomoć, Naklada Jesenski i Turk / Hrvatsko sociološko društvo, Zagreb.

Supek, Rudi (1983), Zanat sociologa - Strukturalna analiza, Školska knjiga, Zagreb.

Vrcan, Srđan (2001), Vjera u vrtlozima tranzicije, Dalmatinska akcija, Split. 